\title{
PUNISHMENT AND PUBLIC RELATIONS
}

\author{
John E Stannard, Senior Lecturer in Law, \\ The Queen's University of Belfast*
}

One striking feature of the contemporary penal system in these islands is the intense public scrutiny given to the sentencing of notorious offenders, and the concern felt at the possibility that such offenders are not getting their just deserts. ${ }^{1}$ In particular, there are several cases in the last few years which illustrate an important and highly influential factor in public opinion with regard to modern sentencing practice, namely anger and resentment felt at what is seen as 'inadequate' punishment meted out on those who bring about the death of others. ${ }^{2}$ The place of public anger and the desire for revenge in the sentencing process is a topic which raises a great many issues for debate at a legal, philosophical and sociological level, but which has not really been discussed to any great extent in the courts. However, the House of Lords has now addressed this and other related issues in $R$ v Secretary of State for the Home Department, ex parte Venables and $R \mathrm{v}$ Secretary of State for the Home Department, ex parte Thompson. ${ }^{3}$ These cases are better known to members of the public as the James Bulger case.

The facts of the case are too well known to need extensive repetition. James Bulger, the victim of the crime, was a child of two years of age. Whilst out shopping with his mother he was enticed away by two boys of ten, Robert Thompson and Jon Venables, and then dragged unwillingly for a considerable distance to a railway line, where he was battered to death and his body placed on the track in the hope that a passing train would conceal the evidence of the crime. Thompson and Venables were subsequently convicted of murder in a trial which excited enormous public attention. In passing sentence on the two boys, Morland J described the killing as an act of "unparalleled evil and barbarity', ${ }_{4}^{4}$ and described the conduct of the accused as 'both cunning and very wicked'.

* I would like to thank Orlagh McCann and Sean Doran for their help in preparing this case note.

1 It was concerns of this sort which led to the provision in section 36 of the Criminal Justice Act 1988 of a right of appeal by the prosecution in certain cases against an excessively lenient sentence.

2 One can cite in this connection the furore over the Herald of Free Enterprise disaster in 1987, with its calls for the company to be prosecuted for manslaughter, and the Stephen Owen case in 1991, in which the accused was convicted of the attempted murder of a reckless lorry driver who had killed his son and received a mere eighteen months for reckless driving. Northern Ireland readers will also remember the case of Penny McAllister in the same year, in which a sentence of five years passed on the accused for manslaughter on the grounds of diminished responsibility after a particularly brutal killing done for motives of jealousy was increased to nine years after a public outcry in the press: see A-G's Reference (No. 2 of 1992) [1993] 3 BNIL 113. This case is discussed further below at note 46 .

3 [1997] 3 All ER 97.

4 Quoted at [1997] 3 All ER 100. Save where otherwise indicated, the facts and background to the case are taken from the opinion of Lord Goff.

5 Ibid. 
Since the two defendants had been convicted of murder, there was only one sentence that the judge could pass, namely a sentence of indefinite detention 'during Her Majesty's Pleasure' under section 53(1) of the Children and Young Persons Act 1933. However, such a sentence could in theory lead to release after a very short time, which would not reflect the gravity of the offence committed. It was therefore the practice of the Home Office in such cases to follow the practice used in relation to sentences of life imprisonment, ${ }^{6}$ and to ask the trial judge to submit a report giving a view as to the actual length of detention which would be necessary to meet the elements of retribution and general deterrence for the offence. ${ }^{7}$ This element, the 'penal element' or the 'tariff', was set by the trial judge at eight years in the present case. After reviewing the recommendations of the trial judge, the Lord Chief Justice advised the Home Secretary that the 'tariff' period should be increased to ten years. ${ }^{8}$

In the meantime, the intense public interest shown in the crime had by no means been diminished by the conviction and sentencing of the two young perpetrators. There was a widespread feeling of anger and outrage at the thought that Thompson and Venables might be free to walk the streets within a comparatively short time, and there were calls in the popular press, and in the Sun newspaper in particular, for the two of them to be kept under lock and key for the rest of their days. ${ }^{9}$ All of this gave rise to strong pressure on the Home Secretary to set a long tariff. In particular, over a quarter of a million people signed a petition organised by the Bulger family calling for Thompson and Venables to be detained for life, while some 4,400 letters were sent to the Home Secretary to the same effect. The MP for the constituency, Mr George Howarth, submitted another petition, this one signed by some 5,900 members of the public, calling for a minimum tariff of 25 years. Last but not least, 21,281 readers of the Sun signed and sent in a printed coupon bearing the following words:

"Dear Home Secretary

I agree with Ralph and Denise Bulger that the boys who killed their son James should stay in jail for LIFE."

Following these and other representations, the Home Secretary decided to increase the tariff for Thompson and Venables to 15 years. In announcing his decision to the defendants, it was stated that he had had regard to, among other considerations

"the public concern about this case, which was evidenced by the petitions and other correspondence the substance of which were [sic] disclosed to your solicitors by our letter of 16 June 1994, and to the need to maintain confidence in the system of criminal justice." 10

The two defendants now brought an application for judicial review, arguing that the 15 year tariff set by the Home Secretary was unlawful and ought to be quashed. Two broad arguments were presented to the

6 See the statements made in the House of Commons on 30 November 1983 (49 HC Official Report (6th series) written answers cols 505-507) and 27 July 1993 (229 HC Official Report (6th series) written answers cols 861-864): [1997] 3 All ER at 109.

7 [1997] 3 All ER at 101.

8 Ibid.

9 Thus one Sun headline read: ' 80,000 call TV to say Bulger killers must rot in jail'; [1997] 3 All ER at 146.

10 Letter of 22 July 1994, quoted at [1997] 3 All ER 101. 
Divisional Court. The first argument was that sentences of detention during Her Majesty's Pleasure under section 53(1) of the 1933 Act were not the same as sentences of life imprisonment for murder, and that it was consequently unlawful to apply in relation to the former the rigid punitive 'tariff' system appropriate to cases of the latter. The second argument was that, even if the setting of a tariff was allowed in cases of this sort, the process of calculation in the present case had been vitiated by a number of procedural irregularities. ${ }^{11}$

The Divisional Court held in favour of the applicants on the first issue, and it was therefore not necessary to consider the allegations of procedural irregularity. ${ }^{12}$ The Home Secretary then appealed to the Court of Appeal. ${ }^{13}$ It was at this stage that the applicants raised what is the most important argument for the purposes of this note. ${ }^{14}$ They claimed that in exercising his discretion with regard to the setting of the tariff the Home Secretary had taken irrelevant matters into account, namely the public clamour for a severe sentence in the present case. ${ }^{15}$ The Court of Appeal by a majority of two to one ${ }^{16}$ agreed with the Home Secretary on the issue of whether he was entitled to set a tariff in principle, but found for the applicants on the ground that in doing so he had taken irrelevant matters into account, namely the public petition and media campaign. ${ }^{17}$ The Home Secretary now appealed to the House of Lords on the latter issue, and the applicants cross-appealed on the former. ${ }^{18}$

The House of Lords therefore had two questions to decide. Most of the five opinions delivered, which take up over 40 pages of the All England Law Reports, are devoted to the issue raised by the cross-appeal: that of the relationship between sentences of mandatory life imprisonment and sentences of detention during Her Majesty's Pleasure, and the legality of setting a punitive tariff in relation to the latter. More important from our point of view, and arguably also from the standpoint of penal practice, are the comments of their Lordships as to the appropriateness of allowing public anger and outrage to impinge on the sentencing process.

On the first issue, it was decided by a majority of three to two ${ }^{19}$ that the approach of the Home Secretary to the setting of the tariff in the present case was fundamentally flawed. The House of Lords was at one with the Court of Appeal in rejecting the notion that considerations of punishment should play no part in detention under section 53(1), ${ }^{20}$ and it was said that there was nothing wrong in principle even in setting some sort of provisional 'tariff' to be served by the person detained. ${ }^{21}$ What was wrong in the present case was the rigidity of the tariff. It was pointed out that under the order made by the Home Secretary the applicants' case would not be considered by the Parole Board until twelve years had elapsed, by

1 [1997] 3 All ER at 101-102.

12 Ibid at 102

13 Ibid.

14 Ibid at 138. Lord Lloyd makes it clear that this issue did not form any part of the applicants'original petition for relief.

15 Ibid at 113-114.

16 [1997] 1 All ER 327 (Hobhouse and Morritt LJJ, Lord Woolf MR dissenting).

17 Ibid.

18 [1997] 3 All ER at 103.

19 Ibid at 98 (Lord Browne-Wilkinson, Lord Steyn and Lord Hope; Lord Goff and Lord Lloyd dissenting).

20 Ibid at 106 (Lord Goff), 131 (Lord Lloyd), 141 (Lord Steyn) and 151 (Lord Hope).

21 Ibid at 119 (Lord Browne-Wilkinson) and 141 (Lord Steyn). 
which time they would have passed from boyhood through adolescence to adulthood. ${ }^{22}$ Moreover, while it was clear that the Home Secretary might review the tariff in exceptional circumstances, these circumstances did not include any evidence of progress by or rehabilitation of the two applicants. ${ }^{23}$ Whilst this might be appropriate in relation to sentences of life imprisonment for murder, it was certainly not appropriate for the very different considerations which applied to sentences of detention during Her Majesty's Pleasure under section 53(1) of the 1933 Act. $^{24}$ Here the very words 'during Her Majesty's Pleasure' implied an obligation to keep the detention under constant review ${ }^{25}$ and the sentence was subject to the overriding principle enshrined in section 44(1) of the 1933 Act and in the United Nations Convention on the Rights of the Child that in cases of this sort the best interests of the child should be a primary consideration. ${ }^{26}$ Moreover, the adoption of a rigid tariff acted as an unlawful fetter on the discretion of the Home Secretary under Part II of the Criminal Justice Act 1991 to order release on licence in appropriate cases. ${ }^{27}$ For these reasons the fifteen year tariff ordered by the Home Secretary in the present case could not stand.

This was enough to dispose of the case, but what of the 'public relations' issue? Here once more there was a divergence of opinion among their Lordships. Dissenting from the majority on this point, Lord Lloyd adopted the reasoning of Morritt LJ in the Court of Appeal, who drew a distinction in this context between a judge passing sentence and the Home Secretary, who was obliged to take into account the need to maintain public confidence in the criminal justice system. ${ }^{28}$ The public representations taken into account by the Home Secretary in the present case might be criticised as illogical, prejudiced and ill-informed, but they nevertheless served to indicate a level of genuine public concern about the case to which he was entitled to have regard. If he were to ignore such genuine concern, and nobody had suggested that the petitions and the correspondence were not genuine, it would have a direct impact on public confidence for the future. ${ }^{29}$ Lord Browne-Wilkinson expressed no concluded opinion on the matter, whilst saying that the courts should be slow to impose judicial procedures and constraints on what was a purely executive function. ${ }^{30}$ The others, however, did not mince their words. Whilst it was only natural that the family of the murdered child should want to express their concern about the level of the sentence, the same could not be said about the other public representations relied on by the Home Secretary in the present case, which were described by Lord Goff and Lord Steyn as discreditable, ill-informed and worthless. ${ }^{31}$ The functions of the Home Secretary in the present case were akin to those of a

22 Ibid at 119 (Lord Browne-Wilkinson) and 155 (Lord Hope).

3 Ibid at 119 (Lord Browne-Wilkinson) and 155 (Lord Hope).

24 Ibid at 122 (Lord Browne-Wilkinson), 140 (Lord Steyn) and 155 (Lord Hope).

5 Ibid at 122 (Lord Browne-Wilkinson), 144 (Lord Steyn) and 155 (Lord Hope).

26 Ibid at 122-123 (Lord Browne-Wilkinson). There is surely a strange irony here, given the nature of the crime committed.

27 Ibid at 123 (Lord Browne-Wilkinson) and 155-156 (Lord Hope).

28 [1997] 1 All ER 327 at 376, quoted at [1997] 3 All ER at 139. However, Lord Lloyd pointed out that even judges took account of public concern over sentencing levels, citing in this connection the increase in the previous twenty years in the tariff for causing death by dangerous driving: [1997] 3 All ER, loc cit.

29 Ibid.

30 Ibid at 126.

31 Ibid at 114 (Lord Goff) and 147 (Lord Steyn). 
sentencing judge, ${ }^{32}$ who was obliged to maintain a detached and dispassionate attitude. For him to take into account public clamour as to the appropriate level of sentence to be imposed in a particular case ${ }^{33}$ was to take into account an irrelevant matter which rendered the exercise of his discretion unlawful.

In the present case the House of Lords were, of course, referring to the functions of the Home Secretary in relation to a sentence already passed by the courts: the functions of the judge in passing a sentence were not directly in issue. However, it is clear that what was said in the case with regard to public pressure was thought to apply with even greater force to judges in their sentencing role. Whilst Lord Lloyd was prepared to concede that public concern over the level of sentencing might have a legitimate part to play in influencing a judge's decision as to sentence, ${ }^{34}$ Lord Goff said that it would be quite illegitimate for any sentencing authority to take into account public clamour to the effect that a particular offender should be dealt with severely. ${ }^{35}$ According to Lord Hope, the requirements of natural justice were that such considerations should be dismissed as 'irrelevant to the judicial exercise's6, whilst Lord Steyn roundly declared that it would be an 'abdication of the rule of law' for a judge to take such matters into account. ${ }^{37}$ Even Lord Browne-Wilkinson, who as we have seen was prepared to concede a fairly broad leeway to the Home Secretary in a case such as the present, did so by dint of categorising his function as non-judicial, saying that 'judicial procedures and attitudes' should not be imposed on what Parliament had decided should be an executive function. ${ }^{38}$ Obviously to his mind at least, much stricter considerations applied to the sentencing judge. ${ }^{39}$

At the level of broad sentencing policy, the approach of the House of Lords in the present case raises many fundamental questions which cannot be dealt with adequately in the space of a note of this sort. In general, there is widespread disagreement among philosophers and penal theorists as to whether notions of retaliation should play any part in the penal process, ${ }^{40}$ but a distinction can surely be drawn in this context between

32 Ibid at 115 (Lord Goff), 147 (Lord Steyn) and 157 (Lord Hope). Here their Lordships were in disagreement with Lord Lloyd (at 139-140) and Lord Browne -Wilkinson (at 126), who were prepared to draw a distinction between the functions of a sentencing judge and those of the Home Secretary in setting a 'tariff' in cases such as the present. See however Doody v Secretary of State for the Home Dept [1993] 3 All ER 92 at 103, per Lord Mustill.

33 Both Lord Goff and Lord Steyn adopted a distinction drawn by Staughton LJ in Doody v Secretary of State for the Home Dept [1993] 1 All ER 151 at 178-179 between public pressure as to penal policy in general, or in cases of a particular type, which could lawfully be taken into consideration, and public pressure directed towards a particular case, which could not: see [1997] 3 All ER at 115 (Lord Goff) and 147 (Lord Steyn). Lord Lloyd, however (at 139), doubted whether this distinction was workable.

34 Ibid.

35 Ibid at 115.

36 Ibid at 157.

37 Ibid at 147.

38 Ibid at 126.

39 This was also the opinion of Morritt LJ in the Court of Appeal: [1997] 1 All ER 327 at 376.

40 The field of debate on this subject is truly enormous, and there is obviously not the space within a note of this sort to attempt even a broad overview of the literature. Perhaps the most uncompromising advocate of retaliation in the 
pressure brought by the victims of crime and pressure brought by newspaper editors and other outsiders. In the former case, there is a large body of opinion which calls for much more account to be taken of victims of crime ${ }^{41}$ in coming to decisions as to sentence; either indirectly through 'victim impact statements' and the like, ${ }^{42}$ or even by allowing victims to make direct representations as to sentence. ${ }^{43}$ It is certainly at least arguable that where the victims of a crime are anxious to see a heavy sentence passed, ${ }^{44}$ this should form a factor, though of course not a decisive factor, in the court's decision. But the same cannot be said of outside media pressure of the sort seen in the James Bulger case, which many would denounce as a highly dangerous basis for influencing sentencing decisions. ${ }^{45}$ At a time when newspapers and the TV are filled on a daily basis with strident and frequently ill-informed calls for 'tough' sentences on the perpetrators of particular crimes, it is refreshing to see a commitment by the highest court in the land to the values of objective and dispassionate sentencing. The very notion of the rule of law, as Lord Steyn so rightly says, is inimical to allowing sentences to be passed on the basis of public hysteria or private revenge. ${ }^{46}$ There is no room for the blood feud in civilised systems of law. ${ }^{47}$

criminal process was Sir James Fitzjames Stephen, who declared that "the criminal law stands to the passion of revenge in much the same relation as marriage to the sexual appetite:" see General View of the Criminal Law of England, page 99. See also Kant, Philosophy of Law (translation by W Hastie (1887)) at page 196; Hegel, Philosophy of Rights, para 101. Others would allow for some degree of retaliation in the criminal process, not as an end in itself, but in order to express society's abhorrence of the crime, or to satisfy the public emotion of resentment against the wrongdoer: see Feinberg, "The Expressive Function in Punishment," in Gross and von Hirsch, Sentencing (1981). For further discussion of this issue see Hart, Punishment and Responsibility (1968); Honderich, Punishment, The Supposed Justifications (1984); Duff, Trials and Punishments (1986); Lacey, State Punishment: Political Principles and Community Values (1988); Duff and Garland, A Reader on Punishment (1994); Wallace, 'Wild Justice' (1995) 70 Philosophy 363.

41 This term can be used to include not only those directly injured by the crime, but bereaved families and other relatives: McCullagh, Study of Crime in Ireland (1996), pp 334-335.

42 See Ashworth, [1993] Crim LR 498; Joutsen, (1994) 3 International Review of Victimology 57.

43 As is done in some of the United States jurisdictions: Erez, (1994) 3 International Review of Victimology 17 at 18.

44 Which may not necessarily be the case; see Erez, op cit, p 21.

45 See Page, The Sentence of the Court (1948), pages 41-42; Kleinig, Punishment and Desert (1973), at page 125.

46 One must be careful in this context to draw the distinction between revenge (the desire of the injured party for vengeance on the wrongdoer) and retribution (defined by Hart as "the application of the pains of punishment to an offender who is morally guilty" (Punishment and Responsibility (1968) at page 9)). Retribution or "just deserts" is a perfectly respectable factor in sentencing.

47 Indeed, primitive systems of law often indicate a move away from revenge and the blood feud to a more impartial and measured response to wrongdoing: see for instance Seagle, The Quest for Law (1941), chapter 3; Kocourek and Wigmore, Primitive and Ancient Legal Institutions (1915), chapter 4; Diamond, Primitive Law Past and Present (1971), page 222 et seq. 
However, as a result of the present case judges are now in an impossible position, caught as they are between the rock of the House of Lords and the hard place of media criticism. What is the judge to do in the next high-profile case where the hounds of public outrage are baying for a severe sentence to be passed? For the judge to allow these pressures to have any influence on the sentence would be, in the words of Lord Steyn, an 'abdication of the rule of law' ${ }^{48}$ Yet if the judge stands firm, and passes the sentence which he or she decides is appropriate to the case, there will not only be the gauntlet of media outrage to run, but the real possibility of an Attorney-General's Reference and a reversal in the Court of Appeal. 49

For the appellate courts to ignore public pressure brought in connection with an Attorney-General's Reference requires both determination and a thick skin on the part of the judges. But if the House of Lords are serious about keeping public pressure out of the sentencing process, they will have to take the bull by the horns, and do for judges what they did for the Home Secretary in the Bulger case. Next time there is a high-profile case involving a supposedly lenient sentence which is then appealed, they must make it clear that the public pressures which may have led to the appeal being made in the first place ${ }^{50}$ had and must have no influence whatever on the sentencing decision at the end of the day. This will not be an easy task. The genie of sentencing by the media has been let out of the bottle by the Criminal Justice Act 1988; it will take more than a single House of Lords decision to put it back again.

48 Above at note 37.

49 It would be naive to suppose that the passing of section 36 of the Criminal Justice Act 1988, which allows for an appeal against unduly lenient sentences, was not itself largely prompted by media pressure. Anyone who takes the trouble to read the Parliamentary debates on the 1988 Act will see that the proposals under discussion were at least in part made in response to public outrage at supposedly lenient sentences passed in a number of notorious cases, including the Ealing Vicarage rape case: see 113 HC Official Report (6th series) cols 1028-1049; 489 HL Official Report (5th series) cols 314-355.

50 It is hard to imagine that public pressure has no part to play in influencing the bringing of an Attorney-General's Reference in cases of this sort. In the Northern Ireland case of Christie in 1992 the wife of an Army captain had her throat slit by the defendant, who was her husband's lover. At the trial, following evidence of mental disorder, the jury brought in a verdict of manslaughter on the grounds of diminished responsibility, and the defendant was sentenced to five years' imprisonment. Following an immense outcry in the press, much of it predicated on the assumption that this was really a case of murder, an appeal was brought and the sentence increased to nine years by the Northern Ireland Court of Appeal: see A-G's Reference (No. 2 of 1992) [1993] 3 BNIL 113. 